УДК 821.І9

ББК $83.3(5$ Арм $)$
ОТ КЛАССИЧЕСКОЙ ТРАДИЦИИ

К СИМВОЛИЗМУ:

ТУМАНЯН - ТЕРЬЯН, ЧАРЕНЦ

(сравнительно-статистический анализ)

(C) 2019 г. Б.С. Зулумян

Институт мировой литературы

им. А.М. Горького Российской академии наук, Москва, Россия

Дата поступления статьи: го марта 2019 г. Дата публикации: 25 декабря 2019 г.

DOI: IO.22455/2500-4247-2019-4-4-252-279

Аннотация: Символизм в восточноармянской поэзии получил наиболее полное воплощение в творчестве Ваана Терьяна и его последователя Егише Чаренца (в западноармянской влияние символизма испытали Тиран Чракян, Мисак Мецаренц, Ваан Текеян, Сиаманто, Даниел Варужан). Отталкиваясь от классической традиции Ованеса Туманяна, они существенно реформировали традиционный стих: от идейно-образного, лексического до метрического уровней. Новыми для армянской поэзии начала века были образы Девушкимечты, Грезы, Наваждения, Другого мира, Сумерек, Любви, разлитой в мире, Космического предела. Наглядно различие поэтик Ованеса Туманяна, Терьяна и Чаренца демонстрируют статистические данные групп слов, отображающих ивет (золотой, серебряный, синий, солнце, свет и т. п.), звук (голос, зов, шепот, звон, крик, молчание и т. д.), а также слова, условно обозначенные как Высший мир (Я, душа, сердце, Небо, Бог, Вселенная, Греза, Мечта и т. д.). Сопоставляются семантические доминанты художественных систем поэтов, анализ статистических данных существенно дополняется и коррелируется контекстным, содержательным. У Ованеса Туманяна образ создается на понятийном, метафорическом уровне, его мир предметно-пластичен, язык не трансформирован, у символистов же формируется новый язык с привлечением новых лексических пластов, созданием неологизмов и, самое важное новым, порой непривычным поведением слов. Художник-творец созидает символистскую метареальность и, как следствие, - новый поэтический язык и образную систему.

Ключевые слова: символизм, классик, Туманян, Терьян, Чаренц, статистика, контекст, цвет, звук.

Информация об авторе: Бурастан Сергеевна Зулумян - кандидат филологических наук, старший научный сотрудник, Институт мировой литературы им. А.М. Горького Российской академии наук, ул. Поварская, д. 25 а, І2І069 г. Москва, Россия.

E-mail: lalazulum@mail.ru

Для цитирования: Зулумян Б.С. От классической традиции к символизму: Туманян Терьян, Чаренц (сравнительно-статистический анализ) // Studia Litterarum. 2019. T. 4, № 4. C. 252-279. DOI: IO.22455/2500-4247-20I9-4-4-252-279 


\title{
FROM THE CLASSICAL TRADITION TO THE SYMBOLIST POETRY: TUMANYAN, TERYAN, CHARENTS
}

This is an open access article

distributed under the Creative

Commons Attribution 4.0

International (CC BY 4.0)

\author{
(C) 2019. B.S. Zulumyan \\ A.M. Gorky Institute of World Literature \\ of the Russian Academy of Sciences, \\ Moscow, Russia \\ Received: March Io, 2019 \\ Date of publication: December 25, 2019
}

Abstract: Symbolism in Armenian poetry manifested itself at most in the works by Vahan Teryan and his follower Egishe Charents. Stemming from the classical heritage of Tumanyan, these two poets substantially reformed traditional verse on different levels, ideological, figurative, lexical, and metrical. The images of the Girl-Dream, Dreams, Other World, Twilight, Love-dispersed-in-th-world were new to the Armenian poetry at the beginning of the $20^{\text {th }}$ century. Statistical the calculations of the groups of words with the meaning of the color (golden, silver, blue, sun, light, etc.), sound (voice, call, whisper, ringing, cry, silence, etc.), and words conventionally grouped as Upper World (self, soul, heart, sky, God, Universe, Dreams, Dream, etc.) demonstrate the difference in the poetics of Hovhannes Tumanyan, on the one hand, and Teryan and Charents on the other. The article juxtaposes semantic dominants of the poems and analyzes their stylistic properties with attention to their content and contexts. While Tumanyan's poetic world is material and concrete and the language of his poems is traditional, symbolists develop a new poetical language that includes new lexical layers, neologisms and, most importantly, defamiliriazation of the ordinary words. The poet-demiurge creates a new symbolist meta-reality that results in a new poetic language and imagery.

Keywords: symbolism, classical tradition, Tumanyan, Teryan, Charents, statistics, context, color and sound.

Information about the author: Burastan S. Zulumyan, PhD in Philology, Senior Researcher, A.M. Gorky Institute of World Literature of the Russian Academy of Sciences, Povarskaya 25 a, I21069 Moscow, Russia.

E-mail: lalazulum@mail.ru

For citation: Zulumyan B.S. From the Classical Tradition to the Symbolist Poetry: Tumanyan, Teryan, Charents. Studia Litterarum, 2019, vol. 4, no 4, pp. 252-279. (In Russ.) DOI: I0.22455/2500-4247-20I9-4-4-252-279 
Одной из особенностей символистского текста является оперирование не только общезначимыми символами, но и, что важно, созидание собственных авторских символов. Очевидно, что смена эстетической парадигмы приводит к лексическим сдвигам, к формированию новой образной системы и поэтического языка. Усиление символической составляющей актуализирует определенные пласты лексики, а именно абстрактного и отвлеченного контингента [8, с. 5-6], новая художественная система, в которой главенствующее место занимает образ иного мира, в принципе непознаваемого, но открывающегося через знаки, символы, стимулировала поиск соответствующих средств выразительности, структуры образа утонченно-рафинированного, конструируемого посредством символов, полутонов, нюансов. Несомненным творческим достижением символизма является звуковая и цветовая инструментовка стиха, открывшая новую страницу в истории поэтического творчества, и армянского в частности.

Рожденный во французской поэзии и немецкой философии, символизм шествовал из одной европейской литературы в другую, и в армянской художественной действительности наиболее полное воплощение получил в творчестве великих армянских поэтов начала XX в. Ваана Терьяна и его последователя Егише Чаренца. Они существенно реформировали стих - от идейно-образного, лексического уровней до метрического.

Принципиальное отличие стиховой природы поэтов-символистов в ее относительной отвлеченности от временных (исторических), конкретно-природных, вещественных примет и, как следствие, в субъективации поэтического содержания, что и составляет наиболее сущностную 
черту поэзии Ваана Терьяна. Жизнь души является тем всеобъемлющим художественным пространством, где разворачивается лирически-проникновенный, утонченно-прекрасный терьяновский мир. В символистской картине мира отражена единая божественно-диаволическая природа Вселенной. Новыми для армянской поэзии начала века были образы Девушки-мечты, Грезы, Другого мира, Сумерек, Любви, разлитой в мире. Универсальная форма элементов невидимого духовного интеллигибельного мира обрастает «плотью» - и, как результат, проецирует бестелесные сущности на предметы видимого мира, составляющие повседневный опыт личности.

Исследователь творчества Терьяна С. Саринян считает, что «только в “Грезах сумерек” можно вычленить целый ряд слов, которые были неизвестны поэзии XIX века: ankarekic (лишенный сострадания, безутешный), varsatap (распущенные волосы), nrbahjus (нежносплетенный), heratsaval (простирающийся вдаль), gexagangur (прекраснокудрый), andoxdoj (без дрожи, трепета) и многое другое». Хотя, как далее показывает анализ поэтики, новизна касается в первую очередь увеличения состава абстрактно-отвлеченного контингента лексики, однако и образы, хотя и составленные из общеизвестных слов, например, «в моем сердце моросит золотой дождь», непривычны и новы. Подобный образ, по мнению исследователя, был невозможен в поэзии ХІХ в. [I, с. 408-470]. В этом ряду цвет и звук, посредством которых поэты пытались отобразить ускользающие знаки иного мира, также обретают иное звучание и смыслонаполнение.

Для создания сравнительно-типологической поэтической картины мы обратимся к поэзии Ованеса Туманяна, стоящего во главе старшего поколения классиков. Его творчество отражает многообразие народной жизни в историко-культурных и бытийных парадигмах, а в центре его мира человек, поэт со своими размышлениями о любви, жизни, судьбе народа со всей гаммой глубочайших переживаний.

Особенно зримо различие поэтических систем выступает в цветовых и звуковых образах - несомненных новациях символизма. Сразу оговорюсь, что исследование не касается оценки творчества армянских поэтов Туманяна, Терьяна, Чаренца, равновеликих в своем роде, - но только предпринята попытка показать различие качественно иных типов поэтического мировосприятия. 
Анализ поэтических текстов армянских символистов наглядно показывает существенные изменения состава языка (точно так же это показывают подсчеты изменений в метрической системе и тропах) [3, с. 4], поэтики и художественного мира в целом [4]. Частотно-семантический анализ некоторых основополагающих понятий был проведен на основе произведений циклов «Грезы сумерек», «Ночь и воспоминания» и «Золотая сказка» Ваана Терьяна (I5 I65 слов) [5, т. I] и «Часы видений», «Радуга» и «Жертвенный огонь» Егише Чаренца (20 829) [7] по количественным и качественным характеристикам в сравнении со стихотворными произведениями Ованеса Туманяна, включенными в первый том «Собрания сочинений» (3I I2I) [6]. Здесь я особо оговорю, что предварительно оставила у Туманяна неравное количество слов, как есть, вместе с подражаниями и детскими стихотворениями; однако в дальнейшем будет целесообразно сократить произведения Туманяна, оставив только чистую лирику, так как у Терьяна и Чаренца представлены символистские циклы. Но и в таком виде результаты дают необходимую картину для сравнения и некоторых выводов.

Наиболее полно изменения в языковом, образном и идейно-художественном уровнях поэтики символистов наглядно проиллюстрировал бы частотный словарь всего лирического наследия поэтов, однако за невозможностью осуществить эту задачу в рамках данной статьи были избраны наиболее характерные для символизма три группы слов: отображающие цвет и иветовые образы, звук и звуковые образы, а также мы привлекли к рассмотрению группу слов, условно обозначенную как Высший мup понятия, имеющие принципиальное значение в символистских текстах, и основополагающие для лирики вообще субъективно личные - $\boldsymbol{Я}$, сердие, душа и некоторые другие. В таблице учтены разные словоформы одного и того же корня. 
Таблица сравнительных подсчетов стихотворных текстов Table of comparative calculations of poems

\begin{tabular}{|c|c|c|c|}
\hline СЛОВА & ТУМАНЯН & ТЕРЬЯН & ЧАРЕНЦ \\
\hline \multicolumn{4}{|l|}{ ЦВЕТ } \\
\hline $\begin{array}{l}\text { nulh - г6: } \\
\text { nult - } 8 . \\
\text { nulnı - } 3 \\
\text { - Золотой }\end{array}$ & 27 & 53 & 6I \\
\hline $\begin{array}{l}\text { Uрдшр - } \\
\text { Серебряный }\end{array}$ & 6 & I3 & 5 \\
\hline Чuщunıјun - Синий & 9 & $\mathrm{I} 2$ & II9 \\
\hline $\begin{array}{l}\text { Uuifnz2ulquqnıj氏 - } \\
\text { Лиловый }\end{array}$ & $\mathrm{O}$ & I & 8 \\
\hline Чuiqu々 - Зеленый & 20 & 8 & 7 \\
\hline Чuрu्रр - Красный & 24 & 5 & 6I \\
\hline Ul - Черный & 57 & 46 & 8 \\
\hline $\begin{array}{l}\text { Unцр - Темный } \\
\text { Uр⿱亠䒑 }\end{array}$ & $\begin{array}{c}44 \\
9 \\
\text { Итого: } 53\end{array}$ & 95 & 59 \\
\hline Iuuцup - Мрак & 35 & 63 & $2 \mathrm{I}$ \\
\hline $\begin{array}{l}\text { Lnıju - Свет } \\
\text { Lnıu }\end{array}$ & $\begin{array}{c}\text { 5I } \\
74 \\
\text { Итого: } 125 \\
\end{array}$ & 85 & 58 \\
\hline Upl - Солнце & 88 & 39 & $\mathrm{I} 32$ \\
\hline Znıр - Пламя & $3 I$ & $2 \mathrm{I}$ & 64 \\
\hline чрulq - Огонь & 5 & 5 & 78 \\
\hline Tuјঠun - Яркий & 52 & 42 & 8 \\
\hline Хunuqujр - Луч & 3 & 2 & 8 \\
\hline \multicolumn{4}{|l|}{ ВЫСШИЙ МИР } \\
\hline Uinıря - Греза & 2 & $\mathrm{I} 2$ & IO \\
\hline Uunn - Звезда & 34 & 22 & 65 \\
\hline Uuunцuð - Бог & 57 & I & 2 \\
\hline fuupun - Судьба & 36 & 27 & $\mathrm{I} 2$ \\
\hline $\mathrm{Eu}-\mathrm{G}$ & I 45 & I9I & 222 \\
\hline Ерuи - Мечта & 58 & IOO & $\mathrm{I} 24$ \\
\hline Eplhip - Небо & 32 & I6 & 39 \\
\hline
\end{tabular}




\begin{tabular}{|c|c|c|c|}
\hline $\begin{array}{ll}\text { Eplquujhя } & - \\
\text { Небесный }\end{array}$ & 5 & 0 & 3 \\
\hline $\begin{array}{l}\text { Znqh - Душа } \\
\text { Znq (все словофор- } \\
\text { мы) }\end{array}$ & $\begin{array}{l}88 \\
200\end{array}$ & 220 & II 8 \\
\hline $\begin{array}{l}\text { Uhpun в им. падеже } \\
\text { Upun - словоформы } \\
\text { Сердце }\end{array}$ & $\begin{array}{c}7 \mathrm{I} \\
79 \\
\text { Итого: } \mathrm{I} 50\end{array}$ & I9I & IIO \\
\hline $\begin{array}{l}\text { Shtiqtipp } \\
\text { Вселенная }\end{array}$ & 22 & 0 & $\begin{array}{c}\text { I } \\
\text { (Shtqupulquiu) }\end{array}$ \\
\hline \multirow[t]{2}{*}{$\begin{array}{l}\text { Lin } \\
\text { Uup - } \\
\text { Горы }\end{array}$} & $\begin{array}{l}37 \\
\text { II } 7\end{array}$ & $\begin{array}{l}8 \\
\text { II }\end{array}$ & $\begin{array}{l}\mathrm{I} 3 \\
\mathrm{I} 3\end{array}$ \\
\hline & $\begin{array}{l}\text { Общее кол. слов } \\
\text { 3I } \mathbf{2 2 I}\end{array}$ & $\begin{array}{c}\text { Общее кол. слов } \\
\text { I5 } \mathbf{1 6 5}\end{array}$ & $\begin{array}{c}\text { Общее кол. слов } \\
\mathbf{2 0} \mathbf{8 2 9}\end{array}$ \\
\hline
\end{tabular}

Статистика, разумеется, дает общую картину словоупотребления, но имеет свои существенные недостатки. В первую очередь это касается того, что не учитывается контекстный смысл, в отдельных случаях играющий решающую роль, о чем мы будем говорить в каждом конкретном случае при необходимости.

Путь символизации в поэтическом тексте проходит также в направлении придания особого смысла привычным словам, имеющим конкретное значение, таким как, например, физическое обозначение времени суток: сумерки, ночь; времен года: осень, зима, весна. Они приобретают дополнительные значения, не имеющие символической нагрузки в обыденной речи, в символистском же мире того или иного поэта они перевоплощаются и насыщаются новыми смыслами.

Выделим группы слов по нескольким направлениям, встречающиеся в исследуемых текстах:

- пространственные (окружающий мир): природа, небо, горизонт, космос, вселенная, луна, солнце, звезды, поля, лес, дорога, путь, в том числе и абстрактные - пустота (amajutjun), беспредельность, бесконечность, и сугубо символические - Мир (арм. ashkhar, в значении иного мира), в том числе к ним относятся и индивидуальные символы: Сумерки (Терьян), Небесный лабиринт, Предел (Чаренц); 
- временные: осень, весна, редко зима; время суток: вечер, сумерки, ночь, рассвет, день;

- чувства, состояния: неопределенность (арм. ті), предчувствие, тоска, ожидание, печаль, светлая печаль, упоение, греза, бред, мечтания, любовь, поиск прекрасного или утерянного когда-то, упование, ликование.

Цвета: золотой, синий, фиолетовый, серебряный, зеленый, серый, темный, черный, белый, пепельный, кровавый, красный, а также свет, луч, лунный, солнечный, ассоциирующиеся с соответствующими цветами.

Звуки: шорох, шепот, шелест, голос, зов, звон (колокольчика, колокола), звуки скрипки, пианино, шарманки, песня, вой, завывание, напев, шум, крик, плач, стенания, рыдания.

Предварительно обратимся к исследованию Р. Ишханяна, он подверг детальному статистическому анализу «Грезы сумерек» Терьяна [2, c. 305-332]. По его данным в цикле, куда вошли 72 лирических произведения (979 слов и 4363 словоизменений), по частоте употребления первое место занимает Я tu (мое, мне - hu, hqd) - 258 раз, ты - pnı (płq, pn твое, тебя) - г98, третье - сердце (uhpu) - 8г, некий (uh) - 87, душа

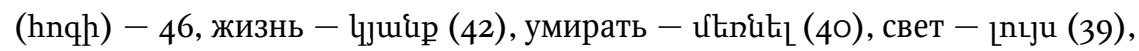

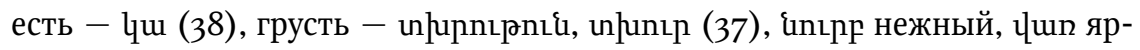
кий, uщјбun сияющий (по 32), он, она, тот - quu (3I), темнота - Unıр (30),

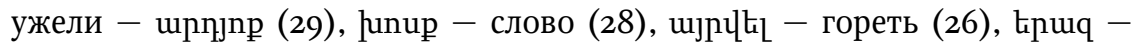

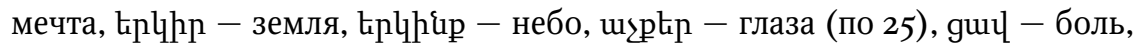
tipp - когда (по 24), htinn - далеко (23), wunı2 - сладкий (сладостный), dunhl - цветок (по 2о), наваждение - gunpp (г4), грезы - uqnıpя (го). Уже на основе данных одного только этого цикла можно сделать некоторые выводы о частоте употребления слов сердце, некий, свет, грусть и т. д., хотя еще раз подчеркнем, что статистический анализ необходимо сопровождать контекстным: к примеру, такие важные для цикла понятия, как грезы и наваждения, занимают в количественном отношении последнее место.

Сравнение статистических данных по всем трем поэтам дает такую картину. По расширенным подсчетам трех вышеуказанных циклов; Терьяна Я (lu, только в им. падеже) - г9г; сердце (uhpun) - 220; душа (hnqh) I92, у Чаренца - 222:I Iо:ІІ8, у Туманяна - I45:200:I5о. То, что «Я» занимает достаточно высокий процент от общего количества слов у каждого из названных поэтов, естественно для лирической поэзии, где, как правило, 
доминирует первое лицо. Однако нюансы, акценты играют здесь немаловажную роль. Даже в этой универсальной для поэзии категории есть существенные различия, исходящие от индивидуальности и поэтического своеобразия каждого из них. Лирическое содержание у Туманяна презентуется первым лицом героя (поэзия Туманяна квалифицируется как лиро-эпическая) наравне с третьим лицом объективного повествователя, в отличие от терьяновской и чаренцевской поэзии, где субъективное начало выражено в максимальной степени.

Основным репрезентантом лирического $Я$ Терьяна, как видно из статистики, выступает такое понятие, как сердие, - 220, по частотности занимающее первое место, а потом уже душа - г92. В структуре его художественного мира знаковый образ мировой поэзии - сердие - является наиболее часто повторяющимся образом, выступающим синонимом лирического Я, полноправным действующим лицом, свидетельствующим о том, что все высказывания поэта - выражение глубоко личных переживаний, интимно-задушевной сферы его дум и мечтаний (для сравнения: такой же мифологемой является сердие в поэзии Вяч. Иванова, выражающей субъективность переживаний и картины мира). Важно иметь в виду, что контекстное словоупотребление Терьяна несколько отличается от общеязыкового. Он не говорит: Я тоскую, а - сердце мое тоскует.

Если у Терьяна основную нагрузку лирического $Я$ берет на себя сердие, то для творчества Туманяна характерен универсальный поэтический образ душа. Очевидные при эмпирическом наблюдении факты преобладание определенных образов, доминирование некоторых понятий - в большинстве случаев находят подтверждение в статистических данных. Так, по статистике, наибольшее количество употреблений понятия душа именно у Туманяна. В его лирических произведениях (баллады и поэмы не учтены) $Я$ - tu употреблено I45 ра3, а душа - 200, сердце (uhpun) - меньше, I50 раз. Причем у него образ Души - лирического $Я$ поэта - обретает вселенский, божественно-демиургический характер, часто в экстраполяциях к библейскому контексту: в его поэзии встречаем такие образно-семантические сочетания, как душа плывет («Армянское горе, бездонное море, пучина бескрайняя вод, / Над этим бескрайним простором душа моя скорбно плывет»); ликует душа («О горы, вновь вдохновленная вами, ликует душа, радостью полна»), голоса души («го- 
лоса души приношу вам в дар»); грусть души («безмерная грусть моей души»); невинные души .

Совершенно другую картину мы наблюдаем у Чаренца. На первое место по частоте употребления у него выходит $G-222$, затем $\partial y щ a-$ II 8 , и в последнюю очередь сердие - гіо. Несомненно, эти данные отражают характерологические черты поэтики Чаренца. В центре его поэзии - человек со своим сугубо личностно-субъективным взглядом на мир и чувственной экспрессией, а не эмоционально-чувственным (Терьян) или божественно-демиургическим (Тумянян) восприятием бытия.

В текстах символистского толка многое зависит от поэтики, общих идейно-художественных установок автора, и, как уже отметили, контекст в определенных случаях меняет смыслонаполнение слов, о чем мы будем говорить по мере возможности. Очевидно, что символистская направленность поэзии Терьяна придает новый смысл привычным словам, создает новую поэтическую реальность. Так, свет у него не всегда имеет положительный смысл, он может быть мертвым, печальным. Также и у Чаренца появляются парадоксальные образы, такие как, скажем, лучезарный мертвеи.

у Туманяна же языковое словоупотребление не искажается, не нагружается дополнительными произвольными смыслами, его неповторимый образный строй, философские обобщения возникают в глубинных идейно-образных структурах. Однако отображенный им мир не остается на линейном, бытовом или только реалистическом уровне, он включен в макрокосм - Вселенную, Космос - Sptiqup. Верхний уровень его картины мира - это Бог; нижний - социальное зло, исторические беды, судьба народа. Не случайно слово - puluun - судьба - употреблено 36 раз, много больше, чем у Терьяна - 27, а у Чаренца и вовсе это понятие находит малое применение - І2. В туманяновский «верхний» семантический ряд включаются понятия: Божественное, звезды, космическое, Вселенная. Присутствие этих понятий не выводит мировосприятие Туманяна за пределы дихотомии земное-небесное, система координат Бог - человек, Космос - земля не нарушена, не создается некая метареальность, характерная для символистского текста. Поэтический словарь Туманяна отражает предметно-вещественные, природные реалии, его поэзия о жизни народа вообще во всей глубине бы-

I Здесь и далее подстрочные переводы всех цитируемых поэтических текстов мои. - Б.3. 
тийной и социальной проблематики. За конкретно-сюжетным содержанием его произведений разворачивается бесконечно глубокий философский пласт. Лирическое «Я» в поэзии Туманяна - олицетворение национального духа, человека, несущего его мудрость и вековую печаль. Не случайно его творчество - символ национальной идентичности, в его творчество в той или иной степени вовлечен каждый армянин. Он сумел соединить самые высокие, книжно-литературно-философские, в том числе символические, пласты с народным мышлением и словотворчеством.

Для Туманяна весь комплекс человеческой жизни вовлечен в макрокосм Божественного мира, для него Абсолют - это Бог Uuuцur. В исследуемых текстах это слово повторяется 57 раз, у Терьяна и Чаренца I и 2. Картина соотношения выразительная и свидетельствует о кардинальной смене мировоззренческих ориентиров. Символистская картина мира становится неопределенно-эклектичной (Бог подразумевается, но не называется), в ней высшую точку занимает иной - совершенный - мир. Символистские представления меняют ценностную парадигму: первое место отдается Красоте и совершенству, в этой ипостаси, соединенной с Добром, в другой - имеющей диаволическую природу.

Бог, Космос, Звезды - неотъемлемая часть поэтического мира Туманяна, он мыслит мир в космических измерениях. Обретая магию туманяновского слова, они (образы) тем не менее не искажаются, не становятся отличными от устоявшихся мистико-философских представлений. Oсобое место в его поэтике занимает Космос - Shtqkpp - 22, Терьян - о, Чаренц - І. Как видим, посттуманяновские поэты избегают конкретного называния пространства. Для них это иной мир, не имеющий названия. В символизме мы наблюдаем совершенно иное - контекстное - словоупотребление: словарное значение нагружается дополнительными смыслами, ключевые для поэта понятия, избранные в качестве символа, становятся самодостаточными и смыслообразующими, доминантными в архитектонике художественного мира.

Однако это не означает, что до символизма поэты не употребляли символы. В основе поэтики Туманяна, естественно, лежат понятия, обретающие знаково-символическую сущность; такого рода отдельные символы не выходят за рамки символической природы искусства вообще. Доминантным образом в его поэтике становятся «горы» - lthitp, uuptp, олице- 
творяющие родной край, в то же время горы - это нравственно-духовный Абсолют, где очищается душа поэта. В данном случае статистика наглядно демонстрирует вышесказанное: - у Туманяна - Llin - 37: uup - II7; Teрьяна - 8-II; Чаренца - I3-I3.

Для текста символистского типа характерны антиномии - полярно удаленные антагонизирующие смыслы, не составляющие единого семантического поля, посредством которых символизм отражает исходную антиномичность мира: внешнего и внутреннего, среды и личности, космического и земного, Этого и Иного мира. У Терьяна система антитез разворачивается в художественном пространстве двух миров: реального и некоего скрытого, таинственного мира, раскрывающегося в пограничных состояниях природы, в экстатических прозрениях сознания, когда греза и творческое воображение приподымают завесу неведомого и в конечном итоге непознаваемого бытия Вселенной. Для произведений Терьяна, как начального периода, так и последующих, характерна отвлеченность от конкретно-жизненных ситуаций, когда поэт не вовлекает в художественное пространство реалии предметно-вещественного мира - и это принципиальная поэтическая установка. Содержание стихов, воплощенное в абстрактно-символических категориях, описаниях состояний души, ее предчувствий и прозрений, сопровождается необычайно прекрасными картинами природы - сумерек, ночи, звездного неба, весеннего цветения. В Природе раскрывается красота мира, но в художественном пространстве Терьяна она всегда - аналог душевного состояния.

Центральное место в эстетике символизма занимает иной мир и связанные с ним понятия мечты, грезы, бреда, небесного. Мечта - универсальная для поэзии категория, особенно многообразно воплощенная в романтической школе, и следом - в символистской, которая во многом продолжает традиции предшествующего направления. Больше всего мечта употреблена (вне автоматизма ожидания) у Чаренца - I24, затем у Терьяна - гоо, и в последнюю очередь у Туманяна - 58, что вдвое меньше, чем в символистских текстах (однако к общему объему его исследуемых произведений, это достаточно высокий процент по сравнению с другими понятиями).

Небо - Łplhıр представлено почти одинаково у Туманяна и у Чаренца - 3І и 39 соответственно, и вдвое меньше у Терьяна - I6 (такие данные требуют контекстного и поэтологического анализа), производное от него 
прилагательное небесный у Туманяна -5 , у Терьяна - о и у Чаренца -3 . Объяснить этот парадоксальный факт - отсутствие у Терьяна и Чаренца эпитета tiplquujh\{ небесный, - видимо, можно тем, что в качестве эпитета прилагательное небесный нагружено романтическими смыслами, что было еще возможно у Туманяна, но отсутствует у его младших современников.

В символистской эстетике иной мир открывается в категориях гре3ы, бреда, сна, дремы. Они приобретают статус особого состояния сознания, когда становится возможным услышать зов инобытия, Вселенной. Уход от действительности в символизме мотивирован принципиальной невозможностью найти идеал, совершенную жизнь: здесь, в этом мире, мы лишь тени, призраки, а прекрасное там, куда мы не допущены, и можем только догадываться о нем, стремиться к нему, наша душа лишь в снах, грезах приближается к утерянной или недоступной нам гармонии. Отсюда и краеугольное значение этих понятий в поэтике символизма. Греза - глубоко личное, неотчуждаемо-интимное отношение к творческому воображению. Основополагающие же для эстетики символизма понятия грезы - uinnn,, наваждения (бреда) - ginnp совершенно не присущи поэтике Туманяна, в исследуемых текстах встречаются 2 раза. Краеугольные для поэтики Терьяна указанные понятия наваждения, бреда ginnp - I4, грезы uinıр2 - Iо, и, как ни странно, у Чаренца греза употреблена 2 раза. Забытье в поэтике Терьяна - неизменный атрибут мистического переживания иного мира, когда сквозь заслоны памяти прорываются воспоминания о дальней стране,

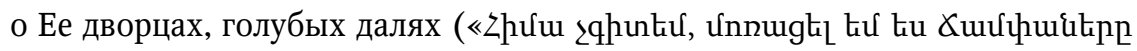
pn: $U_{2} n_{2}$ nı puhuһ» - «Сейчас не знаю, забыл я / Дороги твои. Мгла и тоска»). В образной структуре произведений этого направления важную роль играет основной символистский мотив иллюзорности мира - это и мир, созданный из воображения, и ощущение присутствия мира иного, непознаваемого.

Еще более выпукло особенности символистской поэтики выявляются в цветовых и звуковых образах. Цвет и звук у армянских поэтов, так же как и у европейских и русских символистов, начинают играть смыслообразующую роль.

Впервые в армянской поэзии, традиционно богатой цветовой нюансировкой, в поэтике Терьяна цвет получает не только разнообразные проявления, но и становится самостоятельным компонентом стиха. Цвет у 
поэтов-символистов в именной конструкции переходит от функции зависимого члена (прилагательного) от доминирующей (существительного) основы к смысловой самостоятельности, т. е. получает функцию имени. Существительные, образованные от прилагательных, употребляются уже сами по себе: Золотое, Синее, Лиловое.

Из мистической цветовой триады символистов - золотого, синего, лилового (фиолетового) - у Терьяна вообще отсутствует лиловое, широко присутствует золотой, серебряный и синий. Особенно значим для него цветовой ряд: золотого, серебряного. Самые сокровенные образы-понятия передаются через золотой цвет: у Терьяна золотого вдвое больше, чем у Туманяна - 53 к 27, но меньше, чем у Чаренца, - 6I.

У Туманяна золотой употреблен в качестве эпитета 27 раз, однако в смысловом отношении он не выходит за рамки общепринятых и общеязыковых словоупотреблений. Золото поэт применяет в общепринятых зна-

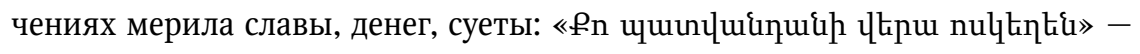

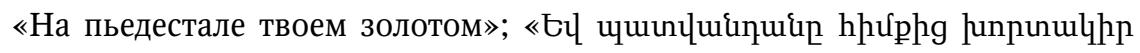
nulp hnpptph» - «И пьедестал ты разруши Золотого тельца»; «3nıp uqů luunitig lu nulh n.pqtg» - «Душу свою растратил и золото накопил» и т. п. Однако, как мы уже отмечали, за жизненным, бытовым у Туманяна всегда встает возвышенный, божественный план. Это, к примеру, золотой луч:

\begin{tabular}{|c|c|}
\hline rर्u unhunıp hnqnuर्u & В моей печальной душе \\
\hline Ouqqnuर $\vdash$ nulh & Рождается золотой \\
\hline 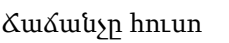 & Луч надежды \\
\hline Zupuunl ljuiph: & Вечной жизни. \\
\hline
\end{tabular}

Это и заря, золотом пылающая: «Єц up2uцnıju nultılun», и мечты

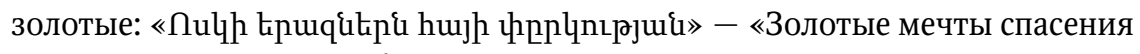
армян»; «nulp tpuqutp ' uppudp qnưuq» - «Золотые мечты, миражу подобные»; лира золотострунная - «Е\{ ppqupn nultuup»; а также простое

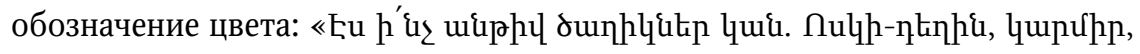

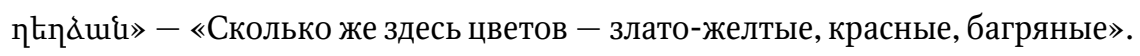

Для Терьяна смыслонаполнение золотого совершенно другое - он репрезентант иного мира, его цвет, сущность, ипостась. Мотив другого мира передается через космические картины вселенной, расцвеченной и освещенной необычными красками, во многих случаях золотым. 
Лирический сюжет протекает в несколько смещенном ирреальном мире, где мы наблюдаем иное словотворчество: непривычные, порой алогичные сочетания прилагательного с существительным, привычные эпитеты в не свойственных им языковых контекстах: это и золотая улыбка ( $\Lambda^{\circ} \mathrm{\downarrow}$

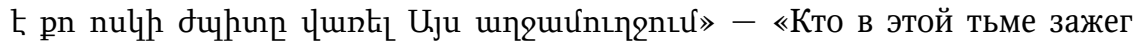
твою золотую улыбку?»), золотая мгла nult 날ㄴ2 huugp, свет золотой - nulh nnıјu, сказка золотая - nulh htphuю и т. д.

Часто золотой связан с солнцем, пламенем, противопоставлен тьме:

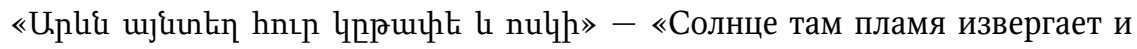

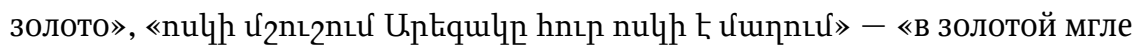

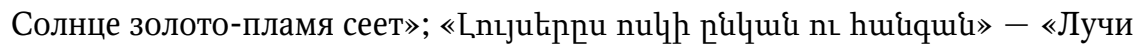

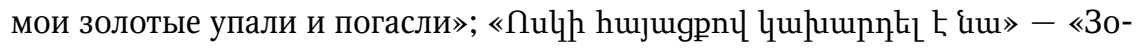

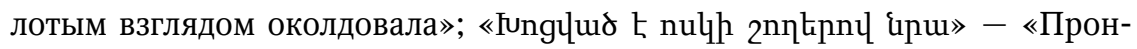
зен золотыми лучами еe»; «ीulh hujugpnl hid uupnıptg» - «Золотым

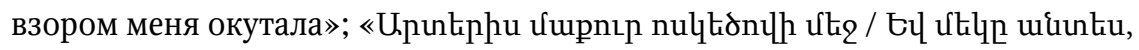

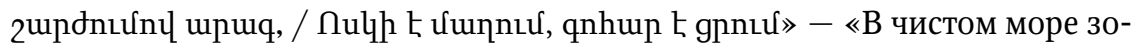
лотых моих полей, / Кто-то, невидимый, взмахами быстрыми сеет золото,

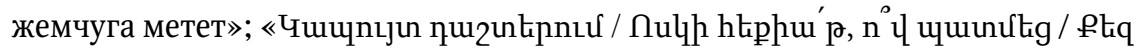

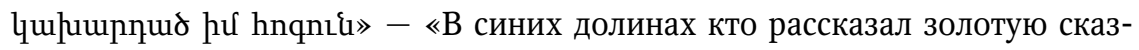

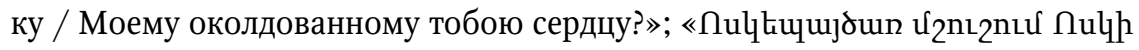
hujugppn duquntu $\downarrow$ hnqnıu» - «B ярко-золотой мгле твой взгляд золотой улыбается моей душе».

Приведенных примеров достаточно, чтобы наглядно продемонстрировать разницу в контекстном употреблении одного и того же слова. В символистском контексте оно получает порой причудливые сочетания, не употребляемые в повседневной языковой практике, однако выразительно презентующие символистское миропонимание и художественный мир поэта.

Ту же картину и принципы языкового и поэтического конструирования образа, что и у Терьяна, мы наблюдаем у его великого последователя Егише Чаренца. Он находит все новые и новые сочетания золотого, одного из самых популярных (можно сказать, и клишированных) эпитетов мировой поэзии.

Егише Чаренц начального периода, в частности в цикле «Страна Пламени» (I9I3-I9I6), творит свой символический мир посредством но- 
вых, доминантных в его поэзии образов - Огня, Пламени, Пожара, Солнца, Солнце-царя, непосредственно ассоциирующихся с цветом золота и красно-багряным. Уже в «Стране пламени» цветовая символика выполняет функцию смыслообразующего фактора. Цвета - Синее, Золотое, Лиловое (фиолетовое) - выступают атрибутами другого мира. Синее (голубое) воплощает небесную суть женского образа - «И в вуалях синих, голубых ты пришла»; Золотое - стихию космической энергии, Лиловое (фиолетовое) - мистические тайны Вселенной. В знакомую символику, выкристаллизованную в поэзии русских символистов и Терьяна в особенности, Чаренц вносит свои оттенки и создает новые метафоры. Специфика его образной системы - в крайней экспрессивности, поэт сталкивает поляризованные смыслы, казалось, несовместимые понятия: огненного и холодного, снежного, белого, лунного света и солнечного. Чаренц актуализирует также символику Золотого и Солнца в системе собственного символистского мировосприятия. В поэтическом словаре Чаренца создаются такие словосочетания, как золотой взгляд, золотая бабочка, золотые огни, в золоте очей, золотой звон, комета, как цветок золотой; золотой мираж. Мотив Золотого у Чаренца активно взаимодействует с мотивом огня, пламени (fng, hntp), крови. Причем в одной строке или четверостишии могут нагнетаться несколько образов огненно-солнечного ряда. Часто, в определенном контексте, они сопрягаются с цветом крови, красно-багряным, что выражает его ощущение гибельности мира:

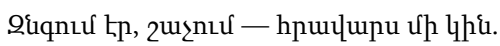
El $25^{\circ}$ np nulh lnulgutp quuhs.

Utinitinntg unų \&pu usptipnıu.

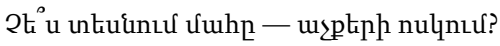

Звенела, стенала огненноволосая женщина.

Ведь были золотые огни

В ее глазах перед смертью?

Ужели не видишь смерть в золоте ее глаз?

Солнце в цикле «Страна Пламени» - выражение его страсти, концентрация эмоций и энергии в светлом солнечном мире. В отличие от цикла «Часы видений», в стихах цикла «Страна Пламени» женский образ получает иное звучание: он поэтизируется в образах безумной мечты, Шамирам, Богини, Хозяйки дальней страны, Огненной женщины. В картины угасающего дня, в отличие от сходной символики Ночи у западноармянского поэта, испытавшего влияние символизма, Мисака Мецаренца и Вечера Терьяна, Чаренц неизменно вносит трагическую ноту: ликование «обманного синего ве- 
чера» - это празднество жертв. Дихотомия чаренцевского символистского образа воплощается в совмещении контрастов: в глазах огненной женщины отражается бесстрастное снежное далеко, снежный венец на огненных волосах - символ возвышенной чистоты, преодолевающей страсть. Пожар, пламень иногда переходят в образ крови, несомненно, ассоциирующиеся с цветовыми образами - золотым, багряным, ало-красным, - придают крайнюю экспрессию поэтическому слову Чаренца и в символистских стихах, и далее, на протяжении всего творчества. Именно образ крови становится доминантным выражением внутреннего драматизма бытия - «Ты со мной была. Кровавая, безумная. // Одинок я был»; «И почувствовал я, что в источающей запах крови, кровавой заре // Вспыхнул белый снежный венеи, твой»; «Ночь с запахом крови», «руки красные, огненные» и т. п. Несовместимость двух миров выражена в тоске героя по свету пожарищ, но огонь женщины - неземной, от него смертельный холод. Цветовая гамма здесь также предельно насыщена, колеблется от контрастных золотого, огненного, красного-кровавого до ослепительно белоснежного. Чаренц неизменно вносит трагическую ноту: ликование «обманного синего вечера» - это празднество жертв. Поэтический мир Чаренца динамичен, вмещает в себя, казалось бы, несовместимые крайности. Один и тот же символ может употребляться в противоположных значениях. Так, в цикле «Жертвенный огонь» все указанные цвета воплощают уже положительные символы. Окружающая природа прекрасна, все залито солнцем, расцвечено красками - голубым, золотым, зеленым. Возносится гимн солнцу, природе. Красный - уже цвет не крови, а «огненно-золотого» зарева, пашни: «И с зарева красное-красное течет вниз, на пашню, пылающее солнщем ликованье»; сердце уподобляется «раскрывшейся красной розе в голубизне неба».

Принципиально цветовое решение идейно-образных смыслов Чаренц находит в цикле «Радуга». Через образ трехцветной радуги он раскрывает образ Голубой девушки. Он разграничивает три сферы - это Синее, Золотое, Фиолетовое, посвящая им отдельные разделы цикла. В одном из стихотворений цикла «Радуга» золотой сопрягается со звоном, создавая необычный образ золотого звона. Он получает мотивацию, когда поясняется,

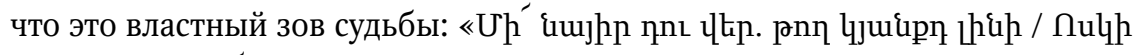

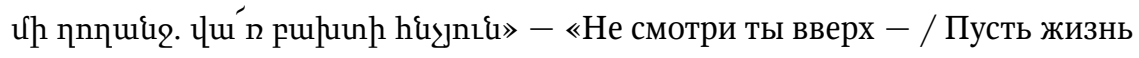
твоя будет золотым звоном, ярким звучанием судьбы». 
Именно в этом цикле цветовые обозначения получают абсолютную самодостаточность. Золото в Синем, Золото Солнца, Золото как олицетворение некоей субстанции - жизни, судьбы, страсти, эмоции, творчества, всего, что созидает Космос. Поэтому поэт призывает голубую девушку, спящую в Синем, проснуться и посмотреть на пылающий золотом крест: «

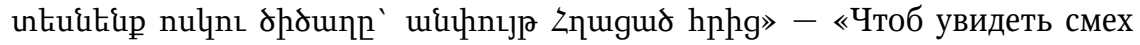
Золотого, беззаботно зачатый от пламени». Такие же необычные образы-метафоры создаются посредством концепта «солнце»: «Солнце - золотая бабочка» или «комета - золотой цветок». Порой золото соединяется с Синим, вечным, звездным: «Uplp pnqlцuљ nulhq». Пламенеющее Золото Солнца осветило золотом синь твоей звездной души.

Статистика словоупотребления солнца, непосредственно связанного с золотым, еще раз подчеркивает глубинные интенции творчества поэтов: больше всего Солнца в творчестве Чаренца - I32, достаточно много у Туманяна -88 , и меньше всего у Терьяна - 39, что соответствует общему настроению и поэтике его творчества.

Те же тенденции обнаруживают словоупотребления огня - црuц и пламени - hnıр: Чаренц - соответственно 78 и 64, Туманян -5 и 3I, Терьян -5 и 2г. Резкое увеличение образов солнца, пламени, огня в поэзии Чаренца - свидетельство его индивидуальных предпочтений, он через эти образы передает и драматизм, и катастрофизм мира, а в цикле «Жертвенный огонь» в сочетании с солнечной символикой - уже противоположную гамму настроений - радость бытия и динамику возрождения. Поэзия Чаренца созвучна образам и мировосприятию младшего поколения русских символистов, для которых Солнце становится ведущим символом, а также - что, может быть, более существенно - актуализирует национальное художественное сознание, в основе которого лежит поклонение Солнцу.

Поэзию же Терьяна можно сопоставить с творчеством старшего поколения русских символистов: в их образной системе преобладает лунарная символика. Поэтому образ и цвет серебра у Терьяна представлен много больше, чем у современников - 13 (хотя это и немного по отношению к общему количеству слов, но имеет концептуальное значение) и всего 6 у Туманяна и 5 у Чаренца.

У Терьяна этот эпитет способствует созданию особенно изысканных поэтических картин и образов, как, например: серебристые слова - «qnigt 
duүumu pn hunuptpnl upдupt» - «Может, улыбнешься ты своими словами серебряными»; серебряная мечта: «El pn hunuptnp undupt tpuq» «И твои слова - серебряная мечта». А также для передачи звукового образа серебристый смех - upðupt дhðuп. Остальные случаи употребления этого эпитета близки к общеязыковым, но опять же служат созданию импрессио-

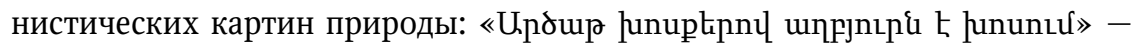

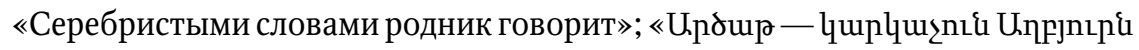
Ł hununud» - «Серебристо переливаясь, родник говорит».

Эпитет серебряный Терьян употребляет для создания ассоциативно-цветовых образов, близких по возвышенности стиля к золотому, но, как правило, в его поэтике оно способствует передаче настроения печали, умирания: «tpp ununıp qqquipnц uptqulц utininn / Uupteph updupt quununfitpq Ł цunnuर...» - «Когда с нежной печалью умирающее солнце / Зажигает серебристые вершины гор». При помощи этого эпитета Терьян творит удивительные поэтические картины природы: «tとl tpp uuphph quunupitip ul Upдup 2nұu» - «И когда черные вершины гор вспыхнут

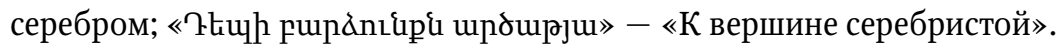

Часто серебро, серебристый сопрягаются с ночными картинами, традиционно с лунным светом, но уже не в качестве эпитета, а имени:

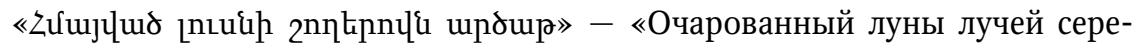

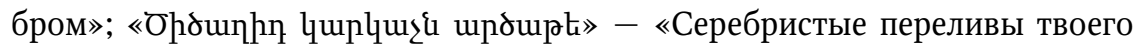

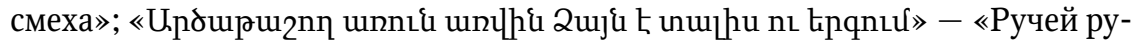

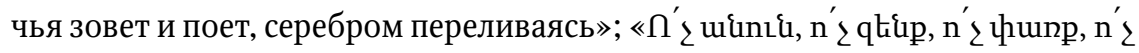
upðuр» - «Ни имени, ни силы, ни славы, ни серебра».

В поэзии Чаренца мы наблюдаем малое количество применения эпитета серебряный, однако тенденция к созданию парадоксальных, экспрессивных образов проявляется даже в этих нескольких случаях, которые встречаются в исследуемых циклах. Это и привычное словосочетание серебристые звезды, в то же время практически не встречающееся

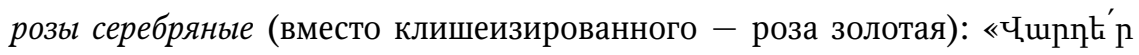
puщku undupt, undupt uunntр» - «Буду ронять розы серебряные, звезды серебряные». Диссонирует также с автоматизмом восприятия кон-

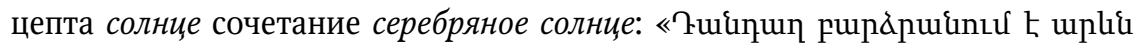
undup৮» - «Медленно восходит солнце серебряное». Наряду с этими слу-

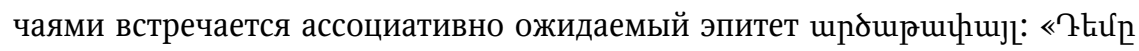




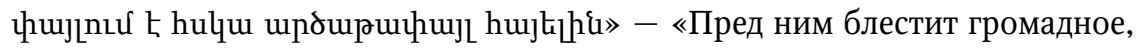
сияющее серебром зеркало».

У Туманяна же эпитет серебряный и серебро в качестве цвета связа-

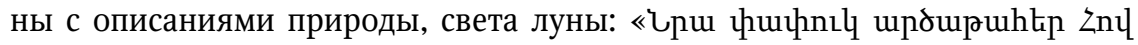

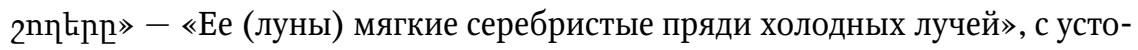

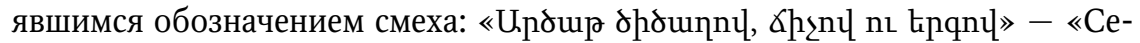
ребристым смехом, криком и песней», в значительной степени способствуя созданию лирико-мистической, волшебной атмосферы его поэзии. Золото, серебро также олицетворяют устойчивый символ денег - «Uuulud $\mathrm{L}_{2} \mathrm{Uqu}_{\mathrm{L}}$ nulnıg, unduphg» - «Создал себе бога из злата и серебра».

Особое место в эстетике символистов занимает Синий цвет, выступая атрибутом иного мира, его знаком. Соответственно творческим установкам поэтов он и распределяется в статистической таблице: Туманян -8 , Терьян - I2, Чаренц - II9.

У Туманяна эпитет выступает большей частью в общеязыковых устойчивых сочетаниях: синее небо, синий небосвод, синие глаза, синяя даль и т. п.

У Терьяна Синего немного по отношению к общему количеству слов, но этот цвет имеет особое концептуальное значение в его поэтике. У него он все еще выступает в связке с именем, но приобретает новые смыслы, обозначая мистический мир или причастные к нему атрибуты. Это и синяя

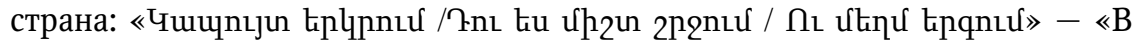
синей стране / Ты кружишь всегда / И нежно поешь»; quuщnıjun utiq - си-

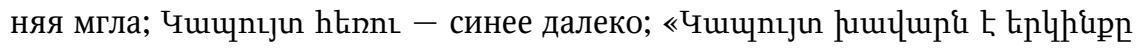

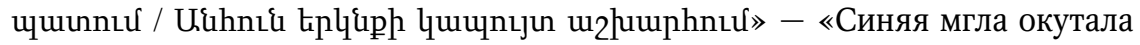
небо / В синем мире бездонного неба»; Чuщиnıыn dudlng - Синее покрывало. В Синем свете происходит самое сокровенное, таинство возможно только в сумерки, Синее - стихия женщины и образ мира:

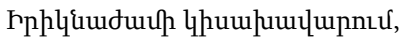

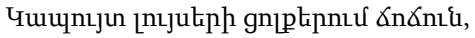

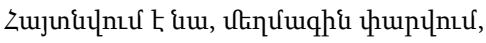

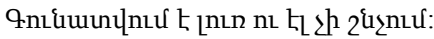

В полумраке сумерек,

В отблесках синих лучей трепещущих, Является она, нежно все окутав, Бледнеет, молчит, и не дышит уже.

Синее у Терьяна активный конструкт ирреального лирического пейзажа: 
nulp Ł ưnnıu, qnhup Ł gnnıu

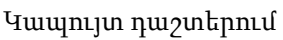

Yuuuntjun durłlyngi hquul gur

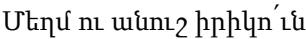

Золото сеет, жемчуга метет

В синих полях,

Синее покрывало опустилось вниз -

Нежнейший и сладостный вечер.

В поэзии Чаренца Синее Чшщпицир обретает функцию имени и полную субстанциальную самостоятельность. Синее символизирует (и есть) вечность, мир, некую сущность, которой принадлежит Голубая девушка (у Чаренца девушка характеризуется тем же эпитетом Чuщицји - Синее, я же перевожу прилагательным голубая, которому в армянском соответствует Łplquuqnuj\{. - Б.3.). Они - девушка и мир - едины. Этому миру принадлежит и сам звездный поэт из страны Аменти. Это название Чаренц взял у французского символиста Альбера Самена, у которого есть цикл стихотворений под названием «Аменти». К 24 газелле из цикла «Радуга» поэт дал комментарий: «B египетской мифологии - закатная, потусторонняя страна» $[7$, с. 357]. Несопоставимо большее количество употребления Синего у Чаренца (II9) по сравнению с двумя исследуемыми поэтами, говорит о сознательной творческой установке автора.

Новые символы его поэзии - Небесный Синий Предел, Космический Лабиринт - неизменно ассоциируются с Синим цветом.

Znqhi Цط utinintu:

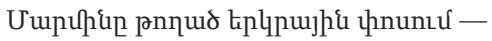
furhunntu t aw unptiqtipulquis

Luphphipnuntu: <...>

fuug ti np lhuukup hnqhu, npultu utiq, uppugurd un qnh,-

Uujpuufntunujh\& Eqkipp Yuuunıju,Łnıju tiqtipp $9 n$...
Душа не умирает. Оставив тело в земной яме Бродит она в Космическом Лабиринте. <...> Но когда же душа моя, как гордая священная жертва, дойдет до Тебя,

До Закатного Синего Предела, - светлого Предела Твоего?

В «Радуге» цветовая символика становится ведущим поэтическим принципом построения текста. Такие образы, как Синее, Золотое, Лиловое (фиолетовое), Голубая девушка, Трехцветная радуга выступают в качестве самостоятельных семантических полей, разграничивающих иной космический мир и этот, земной.

В знаменитом стихотворении «Радуга» образ Голубой девушки ассоциирован с трехцветной радугой: 


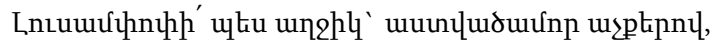

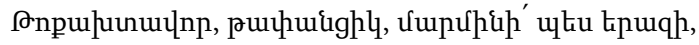

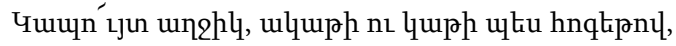

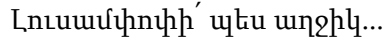

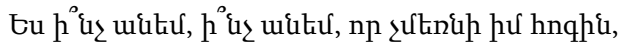
กp zưuph hư hnqhi pn ulqupt usptipnur.

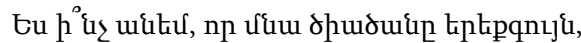
กp zginh, ¿ưuph' hư hnqnı hinnı\&...

Девушка, как лампада, с глазами богоматери, Истонченная, прозрачная, будто тело мечты, Голубая девушка, как агат и молоко, душа трепещущая... Девушка, как лампада...

Что мне сделать, что сделать, чтоб не умерла моя душа В твоих агатовых глазах, Что мне сделать, чтобы осталась радуга трехцветная, Чтоб не испарилось, не угасло моей души далеко...

И в дальнейшем развитии цикла эти ведущие цвета - Синее, Золотое, Лиловое (фиолетовое) - раскрывают различные воплощения Иного Мира.

Большинство произведений написано в форме диалога-обращения к спящей девушке («Синее», I916, І917):
Yuuuntjun hnqnı unnpuifpi Ł, pnıjn,
Синее - души молитва, сестра, -
Guupntjun - puuhpd,
Синее - печаль,

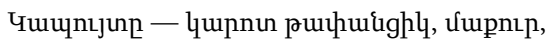
Синее - тоска прозрачная, чистая,

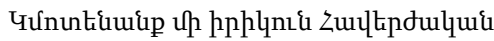
Неким вечером дойдем мы
Guupnıjunha
До Вечного Синего.

Множественность словоупотребления символики Синего разворачивается в бесконечных смысловых нюансах, вот некоторые из них:

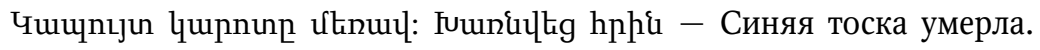
Смешалась с пламенем; 


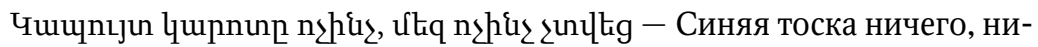
чего нам не дала;

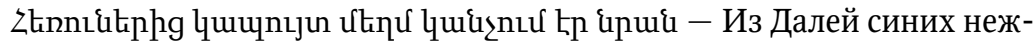
но звала она;

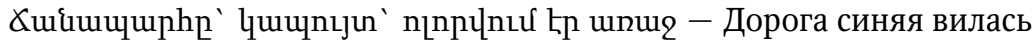
вдаль;

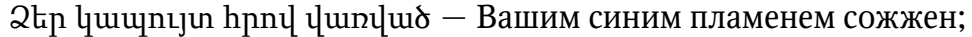

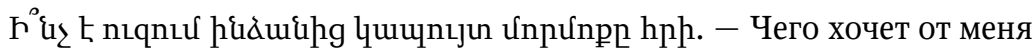
синяя мука пламени;

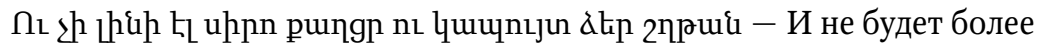
любви сладостная и синяя ваша цепь;

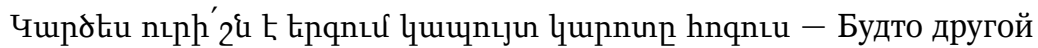
поет синюю тоску моей души.

Цветового обозначения Лиловое - Uuunı2ulquqnıјє у Туманяна и у Терьяна нет вовсе. У Чаренца этот цвет - воплощение мистической сущности Вселенной, отражение его души - hnqhu ưunızulquqnıj\{ моя душа лиловоцветная. Этому цвету посвящен раздел цикла «Радуга».

\section{Звук и звуковые образы}

Вся поэтика символизма связана с темпоральностью, звуковой инструментовкой. Поэтический образ символисты стремятся уподобить музыкальному, так как «музыка непосредственно говорит о невыразимой сущности мира» (Шопенгауэр). «Поэтическое искусство» Верлена провозглашало «музыку» и «оттенки» важнейшими элементами поэтической формы. В русском искусстве особое место занимает трансцендентальная музыка Александра Скрябина, выразившего свою философско-мистическую концепцию мира через утонченную систему символических мотивов: пламени, мимолетности, хрупкости, зова, экстаза (известно, что он сопровождал свои произведения стихотворными текстами).

В поэзии Терьяна и отчасти Чаренца увеличились не только собственно звуковые образы, но и звуковая инструментовка стиха становится самостоятельным смыслообразующим фактором, передающим ассоциации, настроения. 
у Туманяна звуковые образы выступают в функции семантических доминант, связанных с глубинными смысловыми интенциями его творчества.

\begin{tabular}{|c|c|c|c|}
\hline Звуковые образы & Туманян & Терьян & Чаренц \\
\hline $2 u j \mathfrak{u}-$ Голос & 50 & 23 & 27 \\
\hline .2uiq - Звон & I & 4 & 22 \\
\hline Чuiq $-3 о в$ & 54 & 60 & 67 \\
\hline$\chi_{1 々}-$ Крик & 2 & 5 & I4 \\
\hline Z\{々nuju(hiı) - Звук & $\mathrm{I} 2$ & 34 & 23 \\
\hline$\tau_{2} \mathrm{nll}_{1}-$ Шепот & I & I4 & 20 \\
\hline てр2nuju - Шорох & 0 & 4 & 0 \\
\hline Lnın - Молчание & 58 & 23 & 45 \\
\hline Ппр - Плач & $\mathrm{I} 2$ & I & 3 \\
\hline
\end{tabular}

Звуковые образы у Туманяна представлены в большой степени понятиями голос - $2 u j \mathfrak{u}(50)-$ и его антонимом - молчанием - Lnnıpjnıq, $\mathrm{ln}^{\mathrm{nun}}$ (58), высокий уровень словоупотребления также у понятия зов - Чuqц, однако их контекстное поведение в его поэзии также не выходит за рамки общеязыковых моделей. Крика у Туманяна и вовсе нет (2), много больше плача-рыдания nпf - I2, что также отражает направленную на судьбу народа тематику его произведений.

у Чаренца голоса $2 u j\{$ (27) больше, чем у Терьяна, но значительно меньше, чем у Туманяна, в то же время по всей шкале звуковых образов у Чаренца, как наиболее экспрессивного из всех исследуемых поэтов, наиболее высокие показатели: крика $\alpha_{2 々}$ - I4, зова Чui -20 , и противоположного им молчания -45 , и шепота -20 . Однако в этих случаях особенно нужно учитывать контекстное словоупотребление. Иной мир сквозь пелену реальности открывается в знаках, символах, а также посредством некоего голоса, неопределенного некто, который, преображаясь, то «хохочет во тьме», то зовет. Если у Туманяна голос, зов имеют конкретного адресата (голоса детства, родной голос, зов гор), то у Терьяна и Чаренца это почти всегда некий голос. У Терьяна впервые воплощены принципиально новые подходы к созданию звуковых образов, статистика также свидетельствует о высокой степени их присутствия. У символистов и голос, и зов имеют принципиально иное смысловое наполнение - это почти всегда некие, неопре- 
деленные, раздающиеся откуда-то зов и голос, сопровождающиеся неопределенными местоимениями: hi々 np; up - некий.

У Терьяна монотонные повторы сопровождаются перекличками, богатой аллитерацией, создающей дополнительную эмоциональную нагрузку. Звуковая аура его стихов не только усиливает настроение, но и является структурообразующим элементом. В стихотворении «Средь множества людей» через консонантные повторы (т - un, п - u) передается атмосфера уныния, холода. В произведениях Терьяна, где преобладают мотивы безысходности, одиночества, практически отсутствует цветовая гамма, но богато представлены звуковые образы: шум дождя, ветра, стук, завывание, колокольчик, песня, мелодия скрипки, пианино, шарманки и т. д., как правило, инструментованные аллитерационным рядом.

Мотив кружения, бесконечной мелодии воплощен в мелодиях скрипки (ср.: верленовский мотив - «Издалека льется тоска скрипки осенней»), пианино, которая родственна душе, как песнь прошедшей любви. Узнавание себя в мире происходит благодаря созвучности своего переживания далекой мелодии: слышится своя боль в чужой песне, в которой изливается чья-то душевная боль. Однозвучная мелодия подобна осеннему печальному дождю, там за стеной и - в душе: «Звучит без конца, как осень, печально».

Состояние грусти передается через мелодию: чередующийся ритм пятисложника с трехсложником воспроизводит монотонность дождя. Основные смысловые единицы сопровождаются звуковыми характеристиками: грусть поет, дождь плачет, всхлипывает, тогда как героя постигает молчание и забытье: «я брожу один и молчу». Состояние безысходности почти всегда передается через мотив кружения. Забытье сопровождается и слепотой, и немотой.

Однообразное кружение карусели вызывает мысли о бессмысленности жизни, ее бесконечной повторяемости: «Thunцhp, ưunlhp qunntukl, tu pn tinqp lunnıg tư $\mathrm{lut}_{\mathrm{L}}$ - Кружись, кружись, карусель, / Твою песню я слышал давно».

Если репрезентантом иного мира, тайного бытия, наряду с цветом, является некий неопределенный голос или шепот, то атрибутом улицы пространства внешнего, в отличие от внутреннего, - являются не цветовые, а звуковые образы - завывания, вьюги, порывы, удары о дверь ветра, пес- 
ня бродячего музыканта, мелодия скрипки, пианино. Улица символизирует бесконечное кружение в пространстве, мелодия - кружение звучаний, отражающее нескончаемое кружение памяти в прошлых переживаниях, тоске по чему-то прекрасному, но утерянному, и воспоминаниях. В одном из писем Антарам Мискарян (от 9 сентября I9II г.) Терьян точно сформулировал это настроение: «Несказанно люблю уличную музыку, и это плохое пение, и эту бесконечную печаль, которая охватывает меня в это время. Во мне так часто просыпается бродяга, это желание - быть люмпен пролетарием без определенной профессии, бродить по всему свету свободным путешественником, без дома, без связей. И очень часто мне кажется странным, что мы все так суетимся, мучаемся - и все из-за пустяков, и в конце концов возникает вопрос - стоит ли так жить?» [5, т. 4, с. 30].

В противопоставлении суетности мира, настойчиво звучит мотив тишины. Минуты умиротворения в природе сродни тишине, к которой стремится герой - абсолютной тишиной, беспредельной. Злые шумы, пустые слова - это все атрибуты дня. Вместе с сумерками все - звезды, воды должно уснуть, пусть одинокий странник, его сердце больное выплеснет последние слезы, успокоится, затихнет, все пусть молчит, умиротворится, не будет мечты, песни. Романтическое желание уйти, забыться, отдохнуть (Гете, Лермонтов) в символистском понимании Терьяна трансформируется в небытие, полное молчание - «Тишина, тишина, тишина беспредельная». («Похороните меня, когда красный закат угасает...»).

Мотив осени интонируется звуками нескончаемой песни, мелодии скрипки, пианино, рыдания, плача. Больная душа охвачена горькой печалью и воспоминаниями. Ветер, холод, отсутствие веселья - спутники осени. На фоне серых и безрадостных красок, безжизненности единственное яркое пятно - это пламя ревности: золотые мечты и надежды некому зажечь. Вся гамма пессимистических настроений выражается через аналогичные состояния природы - осень, дождь, ненастье. Разочарование и усталость доходят до предельной точки - холода, пустынности, обездоленности, противопоставленной прошлым огням, грезам, рожденным небом.

В стихотворениях, где преобладает мотив безысходности, почти полностью отсутствует цветовая гамма: оголенность, единственный цвет черный свод (небесный), свет - холодный. Звуковая аура - дождь, ветер, и над всем бескрайним простором - «рыдание отчаяния». 
Мастер звукописи, Терьян придавал особенное значение звучанию стиха, завораживая читателя каскадом согласных, переливами гласных в зависимости от настроения и содержания стиха. В «Осенней мелодии» десятисложные строки сочетаются с укороченной пятисложной строкой, звучащей как рефрен - музыкальное эхо, эффект, достигаемый посредством аллитерации. Мелодика стиха от начала до конца инструментована звуком «а», усиливающимся к последнему, третьему четырехстишию за счет количественного нагнетания и интонационной протяжности: I четверостишие - I3 a, 2-9a, 3- I4 а.

Картины облетевшего сада, ветра, плачущего в голых и зябких кустах, дома, опустошенного и темного, и в целом мотивы осени, печали, одиночества у Терьяна, как правило, интонируются звуковыми образами - это плач в саду, звуки нескончаемой песни, бередящие горькую душевную печаль и воспоминания, когда «некому зажечь золотую мечту надежд», стихи же мажорного регистра имеют богатый живописный фон.

Особенно пронзительная интонация осенней грусти возникает благодаря мелодии в виде рыдания скрипки: «Не знаю, откуда льется Скрипки плач грустный», - звучит словно плач бродящего во тьме влюбленного, всеобъемлющий, всепроникающий, безысходный вечный плач-песня. Шепот и шорох как вестники иного мира также имеют важнейшее смыслообразующее значение в поэтике Терьяна, хотя частотность их не так высока. Знаме-

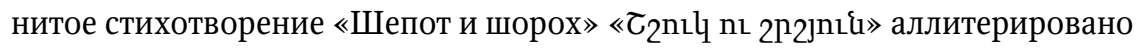
буквой $w$, что создает дополнительную звуковую ауру осени.

Вышеприведенные наблюдения, статистические данные и их описание позволяют сделать несколько предварительных выводов и обобщений. У классика армянской литературы Ованеса Туманяна образ создается на понятийном уровне, т. е. посредством сочетания языковых элементов, у поэтов-символистов формируется новый поэтический язык, с привлечением новых лексических пластов, создания неологизмов и, самое важное, новым, порой непривычным контекстным поведением слов. Поэтический текст сам по себе, по своим изначальным свойствам существенно преобразует объективную языковую реальность в зависимости от идейно-эстетических установок автора, поэтика же символизма направлена на максимальное ослабление референциальных связей, художником-творцом созидается новая символистская метареальность и, как следствие, новый поэтический язык и образная система. 


\section{Список литературы}

I История новой армянской литературы. Ереван: Изд-во АН Арм.ССР, I979. IоІ2 с.

2 Ишханян Р.А. История языка восточноармянской поэзии. Ереван: Изд-во ЕГУ, I989. $428 \mathrm{c.}$

3 Папаян Р.А. Сравнительная типология национального стиха. Ереван: Изд-во ЕГУ, I980. 22I c.

4 Папаян Р.А. Соотношение тонического и силлабического принципов в армянском стихе // Вестник Ереванского государственного университета. I976. № I. C. $180-184$.

5 Терьян В. Собр. соч.: в 4 т. Ереван: Советакан грох, I972-І979.

6 Туманян Ов. Собр. соч. Ереван: Советакан грох, І988. Т. г. 675 с.

7 Чарени Е. Собр. соч. Ереван: Советакан грох,г962. Т. І. 390 с.

8 Чернейко Л.О. Лингво-философский анализ абстрактного имени.

М.: Изд-во МГУ, І997. 352 с.

\section{References}

I Istoriia novoi armianskoi literatury [History of the new Armenian literature]. Erevan, Izd-vo AN Arm.SSR Publ., I979. IOI2 p. (In Armenian)

2 Ishkhanian R.A. Istoriia iazyka vostochnoarmianskoi poezii [History of Eastern Armenian Poetry]. Erevan, Izd-vo EGU Publ., I989. 428 p. (In Armenian)

3 Papaian R.A. Sravnitel'naia tipologiia natsional'nogo stikha [Comparative typology of national verse]. Erevan, Izd-vo EGU Publ., I980. 22I p. (In Russ.)

4 Papaian R.A. Sootnoshenie tonicheskogo i sillabicheskogo printsipov v armianskom stikhe [The ratio of tonic and syllabic principles in Armenian verse]. Vestnik Erevanskogo gosudarstvennogo universiteta, I976, no I, pp. I80-I84. (In Russ.)

5 Ter'ian V. Sobranie sochinenii: $v 4 t$. [Collected Works: in 4 vols.]. Erevan, Sovetakan grokh Publ., I972-I979. (In Armenian)

6 Tumanian Ov. Sobranie sochinenii [Collected Works]. Erevan, Sovetakan grokh Publ., I988. Vol. I. 675 p. (In Armenian)

7 Charents E. Sobranie sochinenii [Collected Works]. Erevan, Sovetakan grokh Publ., I962. Vol. I. 390 p. (In Armenian)

8 Cherneiko L.O. Lingvo-filosofskii analiz abstraktnogo imeni [Lingvo-philosophical analysis of the abstract name]. Moscow, Izd-vo MGU Publ., I997.352 p. (In Russ.) 